\title{
7
}

\section{Socio-cultural Dimensions of Marine Spatial Planning}

\author{
Emma McKinley, Tim Acott, and Tim Stojanovic
}

\section{Introduction}

Within wider marine governance and management, there is an increasing call for greater levels of effective public involvement in marine and coastal issues (McKinley and Fletcher 2010, 2012). Related to this is a need to develop improved understandings and conceptualisations of societal relationships and interactions with the sea. The intricacies, interdependencies and factors influencing these relationships are increasingly being viewed through a sociocultural lens (Bryce et al. 2016). Relations between society and the sea can be underpinned by a broad array of religious, aesthetic, economic and placebased values. Socio-cultural is a broad term that incorporates these many different facets of human society, including attitudes, values, behaviours as well as the structures that frame social organisations and actions. Although hailed as a mechanism through which sustainable management of global marine and coastal resources can be achieved, to date, MSP has given limited treatment to the socio-cultural components of marine use within the planning process,

E. McKinley $(\bowtie) \bullet$ T. Acott $\bullet$ T. Stojanovic

School of Earth and Ocean Sciences, Cardiff University, Cardiff, UK

Greenwich Maritime Centre, University of Greenwich, London, UK

School of Geography and Sustainable Development, University of St. Andrews, St Andrews, Scotland e-mail: McKinleyE1@cardiff.ac.uk 
instead being dominated by economic, ecological and administrative considerations.

This chapter examines a selection of key concepts currently underpinning 'socio-cultural' thinking and draws on examples of social and cultural assessments in marine and other planning contexts. We provide an overview of the breadth of concepts and ideas that fall within this umbrella term of 'sociocultural', before focussing on three key aspects: Cultural Ecosystem Services (CES), Societal Connection to the Sea, and Well-being. Reviewing the use of these concepts in marine planning, the chapter then discusses evidence gaps, key challenges and a series of recommendations as to how contemporary marine planning can better include socio-cultural dimensions.

This chapter:

- describes the range of theoretical perspectives which underpin research on social and cultural dimensions of the oceans, and related debates;

- illustrates examples of how CES, marine citizenship and well-being are applied in MSP;

- discusses the challenges involved in developing a socio-cultural evidence base, particularly in light of the political ecology of coastal space and development; and

- presents evidence as to why a deeper consideration of socio-cultural aspects could be of value to marine and coastal planning.

Recent global initiatives, including, for example, the Aichi Targets and the UN Sustainable Development Goals (SDGs) (UN 2015), place the relationship between society and the natural world at the forefront of international policy development. The connections between society and the sea are dynamic and complex, influenced across spatial and temporal scales by an evolving social, cultural, economic, political and environmental landscape. In order to realise the potential of effective MSP, there is a real need for the sociocultural components of our relationship with the global seas to be better understood and more appropriately embedded within MSP. Evidence from marine planning documents suggests that global marine and coastal governance is developing towards more participatory, integrated and increasingly holistic approaches; there has been a proliferation of MSP efforts worldwide in the 2010s. Cultural components have begun to be considered in these planning efforts, but the efforts have arguably been basic and at a low baseline. In nations with indigenous communities such as Australia and Canada, marine plans have begun to acknowledge cultural perspectives of native societies, 
particularly where this relates to notions of tenure and rights in the sea. In another example, the UK Marine Policy Statement (2011) considers topics such as 'Seascape', 'Cultural heritage' and 'CES', whilst the draft and published marine plans in the devolved nations England (East, 2014) Scotland (2015), Wales (2017) and Northern Ireland (2018) consider those concepts plus other themes such as sustainable 'coastal communities', 'social values' and 'well-being' within their remit. However, how this is realised within the MSP process and operationalised within on the ground, marine and coastal management remains to be seen.

As we continue to understand the role of socio-cultural dimensions within MSP, it is first necessary to consider what this term is actually referring to. Evidence of the terms 'social' and 'cultural' being used interchangeably within environmental governance discourse is commonplace. Within this chapter, we first examine what is meant by 'socio-cultural', investigating the diverse and wide-ranging interpretations of these terms and how they are currently, and could potentially be, used within MSP. Through the chapter, we then explore a sample of emerging concepts from within the socio-cultural arena and consider how these concepts can be more effectively embedded within marine planning.

\section{What Do We Mean by Socio-cultural?}

The social and cultural dimensions of the marine environment are numerous and multifaceted. Cultural interactions between people and the environment are pivotal in the context of broader attitudes and behaviours (Bryce et al. 2016). Relationships between people and the ocean can shape sense of place, personal identity and a broad array of leisure, recreation and work opportunities. Relations can be underpinned by a broad array of religious, aesthetic, economic and place-based values. Socio-cultural is a broad term that incorporates these many different facets of human society, including attitudes, values, behaviours as well as the structures that frame social organisations and actions. Table 7.1 presents an overview of key terms encompassed within the terminology and language of 'sociocultural', including CES, ocean literacy, notions of 'value', place attachment/sense of place and well-being, among others. We acknowledge this diversity of terms, and in the following sections explore a selection of these different approaches to socio-cultural research from the perspective of ecosystem services (ES); ocean literacy, marine citizenship and behaviour change; and well-being. 
Table 7.1 Key socio-cultural concepts and their potential application in marine spatial planning

\begin{tabular}{|c|c|c|}
\hline Concept & $\begin{array}{l}\text { Definition and potential applications in } \\
\text { MSP }\end{array}$ & $\begin{array}{l}\text { Key references and } \\
\text { cross referencing to } \\
\text { chapters and } \\
\text { chapter sections. }\end{array}$ \\
\hline $\begin{array}{l}\text { Cultural } \\
\text { ecosystem } \\
\text { services (CES) }\end{array}$ & $\begin{array}{l}\text { Defined as "the nonmaterial benefits } \\
\text { people obtain from ecosystems through } \\
\text { spiritual enrichment, cognitive } \\
\text { development, reflection, recreation, and } \\
\text { aesthetic experiences" (MA, 2003). This } \\
\text { definition is widely contested. It has } \\
\text { been explicitly used as a framing for } \\
\text { MSP in a few examples. }\end{array}$ & See Sect. 3.1 \\
\hline Ocean literacy & $\begin{array}{l}\text { Understanding of the impact of the sea } \\
\text { on human life, and of people on the } \\
\text { sea-a relatively recent term that has } \\
\text { the potential to engender greater levels } \\
\text { of public awareness, knowledge and } \\
\text { capacity to support MSP } \\
\text { implementation. }\end{array}$ & See Sect. 3.2 \\
\hline Marine citizenship & $\begin{array}{l}\text { Understanding of the individual rights } \\
\text { and responsibilities towards the marine } \\
\text { environment, having an awareness and } \\
\text { concern for the marine environment } \\
\text { and the impacts of individual and } \\
\text { collective behaviour, and supporting } \\
\text { public capacity to have a role in } \\
\text { ensuring ongoing sustainable } \\
\text { management of the marine } \\
\text { environment. }\end{array}$ & See Sect. 3.2 \\
\hline $\begin{array}{l}\text { Attitudes and } \\
\text { perceptions }\end{array}$ & $\begin{array}{l}\text { Public perceptions of marine issues that } \\
\text { explore broadscale and regionally } \\
\text { distinct social perspectives of marine } \\
\text { environments. }\end{array}$ & See Sect. 3.2 \\
\hline Well-being & $\begin{array}{l}\text { Measures of the quality of life. Reflected } \\
\text { in marine plan policies which are related } \\
\text { to blue space and its increasingly } \\
\text { recognised impact on human health and } \\
\text { well-being, and potential criteria for } \\
\text { evaluating the outcomes of marine } \\
\text { planning. }\end{array}$ & See Sect. 3.3 \\
\hline Cultural heritage & $\begin{array}{l}\text { Sets of buildings, monuments or sites, and } \\
\text { also intangible heritage such as cultural } \\
\text { knowledge or practice, which relate to } \\
\text { the marine environment and resources. } \\
\text { Built heritage is often highlighted in } \\
\text { conservation and tourism aspects of } \\
\text { marine plans. }\end{array}$ & $\begin{array}{l}\text { Alegret and } \\
\text { Carbonell (2016) }\end{array}$ \\
\hline
\end{tabular}


Table 7.1 (continued)

\begin{tabular}{|c|c|c|}
\hline Concept & $\begin{array}{l}\text { Definition and potential applications in } \\
\text { MSP }\end{array}$ & $\begin{array}{l}\text { Key references and } \\
\text { cross referencing to } \\
\text { chapters and } \\
\text { chapter sections. }\end{array}$ \\
\hline Seascape & $\begin{array}{l}\text { "An area of sea, coastline and land, as } \\
\text { perceived by people, whose character } \\
\text { results from the actions and interactions } \\
\text { of land with sea, by natural and/or } \\
\text { human factors." Occasionally developed } \\
\text { as supporting evidence for marine } \\
\text { planning through Seascape } \\
\text { characterisation, Seascape assessments } \\
\text { or Visual impact assessments. }\end{array}$ & $\begin{array}{l}\text { Natural England } \\
\text { (2012, p. 1); } \\
\text { Falconer et al. } \\
(2013)\end{array}$ \\
\hline Human activities & $\begin{array}{l}\text { Overviews of sectoral activities in space } \\
\text { and time. Cultural importance of these } \\
\text { human activities to society. Often } \\
\text { quantified and mapped in marine } \\
\text { planning, challenging to assess cultural } \\
\text { significance. }\end{array}$ & $\begin{array}{l}\text { Stojanovic and } \\
\text { Farmer (2014); } \\
\text { Smith et al. (2012) }\end{array}$ \\
\hline $\begin{array}{l}\text { Social values } \\
\text { (monetary and } \\
\text { non-monetary) }\end{array}$ & $\begin{array}{l}\text { Recognition and consideration of a } \\
\text { diverse range of social values, including } \\
\text { drawing on environmental economic } \\
\text { valuation techniques but also broader } \\
\text { social values. }\end{array}$ & $\begin{array}{l}\text { See Chap. } 8 \text { in this } \\
\text { book on social } \\
\text { sustainability. }\end{array}$ \\
\hline $\begin{array}{l}\text { Socio- } \\
\text { demographics }\end{array}$ & $\begin{array}{l}\text { Includes the traditional metrics } \\
\text { considered within socio-demographics } \\
\text { (e.g. gender, age, employment, income, } \\
\text { education level) but also encompasses } \\
\text { other more recent concepts including } \\
\text { coastal typologies and population } \\
\text { projections. Phenomena including } \\
\text { mobility, migration, social justice and } \\
\text { equity. }\end{array}$ & $\begin{array}{l}\text { Links to the work on } \\
\text { social values and } \\
\text { how background } \\
\text { and demographics } \\
\text { can influence } \\
\text { individual value } \\
\text { systems. }\end{array}$ \\
\hline
\end{tabular}

\section{Sociocultural Concepts and Their Place Within MSP}

\subsection{Cultural Ecosystem Services}

Adopting an ecosystem-based approach is becoming increasingly important within marine management and decision-making. The European Commission's EU Directive on MSP 2014/89 states that "applying an ecosystem-based approach" (Art 5, sec 1) is key to marine planning. Consideration of ES is deemed to be central to the ecosystem approach. The concept of CES is 
particularly relevant to MSP, in that its focus is the socio-cultural benefits people derive from nature. However, of the four ecosystem service categories, CES provides the most difficult challenges for identification and assessment. It is not the purpose of this chapter to review contemporary debates in ES; however, in thinking about the application of CES to MSP, it is important to recognise that many similar challenges apply.

With an intellectual tradition dating back to the late 1970s (GómezBaggethun et al. 2010), the concept of ES was placed firmly on the policy agenda through the publication of the seminal Millennium Ecosystem Assessment (MA 2003). The aim of the MA was 'to provide an integrated assessment of the consequences of ecosystem change for human well-being and to analyze options available to enhance the conservation of ecosystems and their contributions to meeting human needs' (MA 2003, p. 2). A framework was provided that distinguished four types of ES-supporting, regulating, provisioning and cultural. CES are defined as 'the nonmaterial benefits people obtain from ecosystems through spiritual enrichment, cognitive development, reflection, recreation, and aesthetic experiences' (MA 2003, p. 58) and may refer to cultural diversity, spiritual and religious values, knowledge systems, educational values, inspiration, aesthetic values, social relations, sense of place, cultural heritage values and recreation and ecotourism.

Since its publication, the issue of CES has been the most problematic category (Satz et al. 2013), with many attempts to articulate relationships between culture and other services (Fish et al. 2016). Although rooted in economics and natural sciences, ES work over recent years has seen closer engagement with the social sciences, with particular emphasis on values and value deliberation (Kenter et al. 2015, 2016a; Cooper et al. 2016). While social science has arguably been admitted to the ES 'club', there are still concerns that the ecosystem framework provides extensive epistemological challenges when thinking about culture and the idea of CES (Leyshon 2014). There is increasing interest to understand CES not just from the social sciences but also from an arts perspective (Edwards et al. 2016). In a recent overview of ES, Costanza et al. (2017) state that cultural services was the least developed category when the MA was published. They point towards the large numbers of papers on CES that have since been published, indicating that there has been some development in this area in the last decade or so. However, there remain major concerns regarding the ability of ES to adequately represent sociocultural perspectives across different world views. For instance, the Intergovernmental Science-Policy Platform on Biodiversity and Ecosystem Services (IPBES) is proposing an approach called nature's contribution to people (NCP) that builds on the ES concept but more strongly 
recognises the 'central and pervasive role that culture plays in defining links between people and nature' (Diaz et al. 2018, p. 270) and elevates the role of indigenous and local knowledge. This approach is strongly criticised by the editor of the journal Ecosystem Services (Braat 2018). At the very least, this exchange demonstrates the evolving nature of the concept and deep divisions that exist.

Although research into ES has grown considerably over the past decade, most studies have had a terrestrial focus, and there is a knowledge gap relating to marine and coastal ES (Liquete et al. 2013). In their systematic review, Liquete et al. (2013) identified 145 papers that specifically assessed marine and coastal ES. They conclude that social sciences are under-represented in the studies, and one of the main gaps are indicators related to cultural services. Beaumont et al. (2007) provided an overview of the ES provided by marine biodiversity. Börger et al. (2014) highlight various valuation techniques which could be applied at different stages of marine planning and regulation, and Arkema et al. (2015) apply an ES framework to the coastal and marine planning process in Belize, highlighting the difference in resultant evaluations of future scenarios when these benefits are included in the planning process. Despite these studies, there are relatively few examples of published work that explicitly connect CES and MSP, although there is a fast-growing body of work that deals with the CES of marine and coastal spaces that might be of interest to marine spatial planners. Examples of the former include Ruiz-Frau et al. (2013), who state that MSP should account for all aspects of value associated with marine biodiversity, meaning that a holistic approach is needed that includes ecological, social and economic aspects. Using a questionnaire approach, their study focussed on providing an economic assessment of nonextractive uses of marine biodiversity.

Guerry et al. (2012) make the case for using the broader ES concept in MSP, 'The framework of ecosystem services enables the explicit examination of trade-offs in services and it provides a quantitative approach for assessing the value of MSP versus sectoral or uncoordinated planning' ( $\mathrm{p}$. 108). To achieve this, they developed an approach called the marine Integrated Valuation of Ecosystem Services and Tradeoffs (InVEST) which was designed to assess the multiple services provided by marine ecosystems. Cultural services are included as part of their framework and recognition that understanding and accounting for cultural values (such as existence, subsistence and aesthetic values) are fundamentally important for coastal communities. InVEST was designed to provide results grounded in both local ecological knowledge and, also, reflect diverse values, conflicts and aspirations. 
Where InVEST takes a whole ES view, Gee et al. (2017) focus specifically on understanding the importance of culture and suggest that cultural values associated with the sea tend to be a neglected aspect of MSP. They discuss the sociocultural evidence gap is a result of the difficulties in defining and eliciting cultural values but also in attributing values to particular places that can then be used in the context of area-based approaches to management. For the authors, a CES approach is just a starting point for thinking about how communities are connected to the sea, and they propose a method for developing 'spatialised' community-based narratives that can be used to identify 'culturally significant areas'.

The importance of developing participatory mapping of ES as a way to navigate coastal values is explored by Klain and Chan (2012), who suggest that monetary and biophysical dimensions tend to dominate spatial planning. They use social value mapping methods to explore how tangible and intangible values are associated with particular locations in the hope of highlighting the underappreciated ways in which ecosystems are important to people. Their study concludes that 'many people attach strong and diverse values to nature, but that spatially identifying and quantifying the importance of particular places is only possible for some people and values. This suggests that planning and decision-making will be most effective and appropriate when they include a deliberative component' (p. 112). In a general review of the priorities for coastal and marine spatial planning (Halpern et al. 2012), the authors suggest that an ecosystem-based process should be preserving critical ES; a key hurdle is how to measure and compare very different ES such as cultural values versus a more easily marketable service or benefit, such as seafood. MSP is seen as an important step in the implementation of comprehensive ecosystem-based management.

Moving beyond the literature that explicitly frames a socio-cultural approach in ES in the context of MSP, there is a growing body of work dealing with the ES of marine and coastal spaces which might find application in MSP. CES feature to a lesser or greater extent. The intention here is to selectively draw from this literature to examine the inclusion of CES in broader policy-relevant studies. Turner and Schaafsma (2015) provide a broad overview of coastal ES in their edited book in which Saunders et al. (2015) suggest that social information is often lacking in the context of coastal ES data. Luisetti et al. (2014) suggest that coastal zone ES that can be valued in economic terms with CES considered as meaningful places supplying a range of goods and benefits. Barbier et al. (2011) give a broad review of the value of estuarine and coastal ES, and Hattam et al. (2015) examine ES broadly in the marine environment 
and then examine a case example of the Dogger Bank in more detail. Both studies make reference to CES as one type of service.

Fletcher et al. (2011), Jobstvogt et al. (2014) and Potts et al. (2014) all consider CES in the context of marine protected areas (MPAs) and marine habitats. They point out the links with human activities such as sport, recreation and nature watching, but all highlight the paucity of data available for making assessments. Fletcher et al. (2014) examined marine CES in the Black Sea. The importance of understanding people's 'experiences' of the sea (beyond recreation) and the deep sense of connectivity that goes beyond the physical properties of objects is stressed. The research illustrates the broad range of sociocultural considerations that are relevant to MSP beyond leisure and recreational opportunities. Where broader ecosystem service studies are carried out, recreation is often the focus of the study (see, e.g. Hynes et al. 2018). However, Baulcomb et al. (2015) suggest their work is the first non-market valuation study to formally consider culture as a generator of ES in a marine environment. They propose an approach to CES valuation that pairs ecological and cultural insight within an ES typology. Pushing the methodological boundaries, Kenter et al. (2016b) integrate deliberative monetary valuation, storytelling, subjective well-being and psychometric approaches to elicit the CES values in proposed UK MPAs. Their study explicitly considers the role of shared values in decision-making. Bryce et al. (2016) recognise the difficulties of assessing CES and suggest a novel framework developed by the UK National Ecosystem Assessment (UKNEA) to evaluate the CES benefits of 151 UK marine sites to recreational sea anglers and divers. Ranger et al. (2016) describe an approach for exploring deeply held cultural values using the Community Voice Method (CVM) set within a deliberative-democratic framework for decision-making with regard to MPAs.

Murray et al. (2016) consider the importance of finding better ways to incorporate social data into decision-making processes and uses the idea of marine socio-ecological systems and integrated ecosystem assessment. Their findings highlight the tension between the need to reduce complexity into measurable indicators and the danger of valuing only what can be quantified (often in an economic sense). Mixed methods using quantitative and qualitative approaches are suggested as a middle ground.

In summary, there is a growing research interest in cultural values and ES (including well-being, which is discussed in Sect. 3.3) allied to management and decision-making around the marine environment. Within the CES literature, there are significant debates on how to appropriately measure or assess the cultural values of ecosystems with inputs from economics, social science and, to a lesser extent, the arts and humanities. There has been some direct 
attempt to reflect on CES in the context of MSP, but by far the largest number of reports are those that study marine and coastal environments through the lens of CES in the broader context of management, rather than specifically for MSP. Incorporating sociocultural values into decision-making encounters challenges of using assessment methods that are acceptable within a decision-making framework. The area of shared values and value deliberation seem to offer potential ways forward for capturing a range of deeply held cultural values alongside other ES assessment procedures for MSP.

\subsection{Societal Connection to the Sea: Values, Perceptions and Citizenship}

Our global seas and coasts provide a rich diversity of goods and services that communities of all shapes and sizes derive a range of benefits from. These interactions and exchanges have a direct influence on the relationships and sense of connection garnered between the marine environment and individual people, as well as society as a whole. Increasingly, social science disciplines and techniques are being employed as a mechanism to delve more deeply into these interactions, resulting in what has been a recent exponential growth in research around the emerging themes (within a marine and coastal context) of public perceptions-based research (Jefferson et al. 2014, 2015; Potts et al. 2016), social values (Ives and Kendal 2014; Schwartz 1992), marine citizenship (McKinley and Fletcher 2010, 2012; Fletcher et al. 2012) and ocean literacy (Costa and Calderia 2018; Uyarra and Borja 2016; Steel et al. 2005).

Cumulatively, these concepts (as described and defined in Table 7.1) allow us to develop a comprehensive understanding of the various ways in which society interacts with, and uses, the marine environment. Importantly, with a common grounding in the social sciences, these concepts provide a 'social lens' through which use of the sea can be viewed. Using techniques, theories and concepts from sociology, psychology and environmental economics, there is a growing recognition that society comprises multiple audiences and that this heterogeneous group possesses a highly mixed set of values, attitudes, perceptions, beliefs and experiences about the marine environment, all of which must in some way be taken account of within MSP.

'Social values', as a concept, has been considered within the disciplines of psychology, philosophy, economics, human geography, anthropology and, now increasingly, within the world of environmental management and conservation (Ives and Kendal 2014). The varying interpretations of the word 'values' itself is challenging; however, the concept can be broadly defined as 
the underlying values held by individuals and society as a collective, and the value attributed to items, things and places (Ives and Kendal 2014). For the purposes of this discussion, 'social values' is also taken to encompass the parallel notions of public perceptions, attitudes and beliefs. Increasingly, the concept of social values and their role is becoming more and more commonplace within environmental decision-making (Tallis et al. 2008). Within a marine context, this can be seen throughout the conversation surrounding the recent European Maritime Spatial Planning Directive, for example. There is evidence of this move towards a more inclusive way of thinking in, for example, the UK's recently published 25 Year Environment Plan (UK Government 2018). This shift in the debate surrounding MSP, while welcome, poses a number of critical questions - what are the social values that should be taken account of within MSP? How do coastal communities (and those not directly living or working at the coast) attribute value (both monetary and non-monetary) to different aspects of their marine environment? How might these values change as a result of MSP-related decision-making, such as licensing of certain activities? What impact might this have on the social and cultural character of the region/town/coastline, and how will this influence its capacity to deliver on sustainable development and the blue growth agenda underpinning MSP?

Traditionally, emphasis has been placed on ascertaining the monetary value of marine and coastal ecosystems, with economic-based metrics used as leverage within decision-making and governance (Tallis et al. 2008). More recently, however, there is a recognition of the importance of other value types, acknowledging that many marine and coastal resources are not easily marketable, making economic valuation complex, partial and even inappropriate in some cases (Kallis et al. 2013; Dempsey and Robertson 2012). By understanding the diverse set of values (both monetary and non), views, perceptions and attitudes held by society about both the local and global marine environment, there is an opportunity for MSP to more effectively recognise the intrinsic complexity of societal interactions with the global seas. Marine and coastal governance, and by association MSP, is at the cusp of a wave, with public interest in marine issues recently reaching a peak through the 'Blue Planet Effect' (The Guardian 2018) and other studies that explore public awareness of marine issues (see for example, Potts et al. 2016). This is therefore an important potential juncture to link public attitudes and MSP processes. Recognising the role that this evidence could play in MSP is just the first step; there is now a real need to develop standardised, effective pathways to incorporate these data in MSP.

Following on from the dialogue around social values, the interconnected concepts of marine citizenship and ocean literacy are an ideal framework to be 
embedded more effectively within the broader MSP processes as a way of ensuring sustainable use of marine resources, with guidance and management accepted and implemented more easily as a result of a more marine aware society (McKinley and Fletcher 2010, 2012; Fletcher et al. 2012). Marine citizenship, derived from the traditional concepts of environmental citizenship (e.g. see Hawthorne and Alabaster 1999), builds on early concepts of ocean citizenship (Fletcher and Potts 2007), which is defined as 'an awareness of the rights and responsibilities towards the marine environment, and an awareness and capacity to engage in management' (McKinley and Fletcher 2010). Marine citizenship sets out a framework that takes the influence of socio-demographic factors (e.g. gender, age, employment history, education level and ethnicity) on individual and collective values into account (see Table 7.1). Complementary to the notion of marine citizenship is the parallel agenda of ocean literacy (Uyarra and Borja 2016; Steel et al. 2005)_each of these seeks to understand and inculcate greater levels of public engagement with marine issues, ultimately leading to positive behaviour change. A relatively new term, ocean literacy was initially coined in 2004 and defined as 'the understanding of the ocean's influence on humans and of our influence on the ocean' (Uyarra and Borja 2016). Fundamental to the concept of ocean literacy, and indeed that of marine citizenship, are the interdependencies that characterise the society-sea relationship, and that society has both rights and responsibilities towards the marine environment, its resources and their use and experience of it. By leveraging the models of ocean literacy, or that of highly engaged marine citizens, and entrenching these processes as fundamental components of the marine planning process, MSP has the potential to not only deliver sustainable development and management of blue space but also engender more marine-aware communities.

Despite garnering increasing attention as a recognised evidence gap, there appears to be limited emphasis on these sociocultural aspects of human interactions with the global marine environment. A review of the UK's Marine Policy Statement (DEFRA 2011), a high-level policy document signed by the four devolved administrations of the UK, and the current versions of the devolved marine plans highlighted a significant lack of consideration of the social values, perceptions- and attitude-based data commonly associated with the concepts discussed in this section, with no explicit mention of these concepts in any of the documents. Despite the use of a somewhat narrow lens to view societal relationships with the sea (i.e. through resource use, and the blue growth agenda), global conversations are making increasing moves to take account of the less tangible aspects of 'value'. Wales, for example, has recently introduced new legislation centred on achieving social, cultural, economic 
and environmental well-being, through the aspirational Well-being of Future Generations (Wales) Act (2015) (see Sect. 3.3 for more on well-being within MSP). On an international stage, the objectives set out by the Aichi Targets and the UN SDGs (specifically SDG 14) echo this attempt to consider society as part of the environmental system. The concepts and frameworks discussed in this section are a valuable lens through which the complex web of societal connections with the sea can be explored. To date, they have not been utilised to their maximum potential to realise change (see, e.g. Costa and Calderia 2018)_MSP is an opportunity to move this forward.

\subsection{Well-being}

Well-being is a multidimensional concept in the social sciences which refers to happy, healthy, prosperous or flourishing people or communities. It is an idea which can be traced back to ancient philosophy and notions of 'the good life'. More recently, the term has come to prominence globally as nations and international organisations have begun to promote novel measures of the success of policies (OECD 2011). Thus, marine plans and policies will be increasingly scrutinised to consider their potential to contribute to greater well-being for people. Some have argued that current governance overemphasises economic prosperity, and well-being is a counterbalance for planning systems to consider the broader contributions to people's quality of life (Stiglitz et al. 2009). In response to this growing interest, a range of disciplines with varying interpretations of well-being have begun to research well-being in relation to the oceans.

Firstly, in environmental psychology and medicine, ${ }^{1}$ there has been a particular focus on 'blue space'-coined in contradistinction to 'green space' to reflect the importance of water-based environments and the health benefits which people get from engaging with coastal or ocean outdoor spaces. For example, Wyles et al. (2017) show that visits to coastal locations produce higher psychological restoration benefits than urban greenspaces, based on an extensive survey. Furthermore, White et al. (2017) report improved emotional and cognitive restoration due to engagement with wildlife, especially where marine wildlife exhibits fascinating behaviours, based upon a study using an experimental approach. A range of recent studies consider how factors such as

\footnotetext{
${ }^{1}$ Studies in medicine have also considered how degraded marine environments can have negative consequences for physical health through disease or injury. Examples include increased risk of drowning due to floods, exposure to pathogens or harmful algal blooms.
} 
type of activity, frequency of exposure and proximity of habitation to the coast affect psychological benefits or reported life satisfaction. Overall reviews conclude that there is moderately strong empirical evidence for the positive effect of blue space on mental health, with less consistent evidence on the relationship to general health, obesity or cardiovascular outcomes (Zufferey 2015; Gascon et al. 2017). Research in environmental economics also considers the premium that people are willing to put on interactions with blue space, such as a home with a sea view. However, the economic concept of welfare is narrower than well-being, which extends beyond financial or material benefits or the health of an economy (McGregor and Pouw Nicky 2017).

Secondly, in cultural geography, anthropology and sociology, there have been investigations of the relationship between affect, emotion and place in marine and coastal settings. In contrast to psychological and health studies, these are often based upon qualitative studies which undertake detailed exploration of phenomena, in order to understand the nature of human experience in or by the oceans. For example, Foley (2015) uses oral histories of outdoor swimming in coastal locations to document numerous responses to immersion in the oceans as 'a place where the body can let go'. Kearns and Collins (2012) report feelings of anxiety and anger when coastal developments are seen to conflict with notions of sacredness or place attachment, while Urquhart and Acott (2013) consider how the collective identity of coastal communities draws upon fishers' engagement with oceanic spaces, particularly emotional attachment to places in the sea, and a sense of freedom. The importance of place as a dimension of well-being is explored in Acott and Urquhart (2017) and White (2017) as part of an edited volume on social well-being and the values of small-scale fisheries (Johnson et al. 2017).

Thirdly, in political economy, development studies and sustainability science, there is considerable research exploring the links between the quality of the environment, access to resources and well-being in terms of overall quality of life (Breslow et al. 2016; Biedenweg et al. 2016; Daw et al. 2015). Wellbeing is a key term in a number of frameworks - for example, it is postulated as the ultimate 'good' to which the benefits of ES contribute (Russell et al. 2013). One reason that people have argued for the use of well-being in planning is its ability to connect political narratives with people's everyday lives, in contrast with more monodimensional measures such as gross domestic product (GDP) or other sustainability indicators which seem removed from their existence (McGregor 2014). Well-being presents a framing for stakeholder engagement in marine planning. Thus, an identified problem such as deprivation in coastal communities, can be engaged via community debate about 
which qualities of the marine area or future scenarios for the oceans will give rise to improved well-being.

Debate continues about how well-being should be measured and operationalised. This is perhaps unsurprising, given the multidimensional character of the concept. One way of categorising different measures of well-being is to consider broadly material/objective, subjective and relational measures (McGregor et al. 2015). Material/objective measures include tangible assets or physiological characteristics. Subjective measures include people's reported perceptions such as their emotional state or level of satisfaction. Relational measures consider life lived in the context of social interactions. Coulthard (2012) presents a 3D conceptualisation of well-being which draws upon each of these dimensions. Despite this rich picture of well-being, there still remains a challenge of how to aggregate these different measures to inform MSP.

\section{$4 \quad$ MSP and Socio-cultural Dimensions: A Critique}

The studies discussed in the sections earlier indicate a growing socio-cultural evidence base that could be used within MSP and have showcased examples of the opportunities and potential associated with this. However, it should be recognised that it would not be simple to just draw upon these studies to support plan/policy development; challenges remain. The following section provides a short commentary on our views as to the key challenges associated with embedding sociocultural factors within MSP.

- Qualitative studies, which are the most common approach within sociocultural studies, although insightful, are sometimes difficult to generalise beyond the context in which they were developed. There is, therefore, a need for greater standardisation of methods and approaches, and development of effective pathways to utilise data of a qualitative nature within MSP. Furthermore, there is a need to identify effective pathways that support the incorporation of diverse epistemologies that offer rich insights into cultural beliefs, values and practice into MSP.

- Quantitative large-scale studies tend to be favoured as an evidence base in planning processes, but it should be recognised that they also have some weaknesses. For example, because of the need for large data sets to support multivariate analyses, they tend to depend upon existing data sets which were not designed for the purpose of MSP and make broad assumptions 
for many of their measures — for example, assuming protected area status as a proxy for high-quality biodiversity or pristine site, when measuring the effects of environmental quality on well-being.

- Challenges remain as how the ideas of space and place across marine and terrestrial borders can be reconciled in ways that satisfy the needs of both groups of planners and decision-makers.

- From a well-being perspective, the literature discussed in Sect. 3.3 presents a range of findings about the connections between well-being and blue space. However, it is not yet sufficiently advanced to operationalise this in a therapeutic framework that can be effectively embedded within MSP.

- A marine plan truly based around achieving well-being outcomes might lead to a different set of priorities.

- Evidence from studies such as those discussed may support policies such as improved coastal access, but there are trade-offs between this and conservation objectives. Considering how well-being arises in an offshore space and accrues to different land-based populations or interest groups is complicated for marine planning to consider.

- Marine plans themselves are not always the appropriate regulatory framework for well-being policy - these policy interventions might be developed in other fields such as public healthcare. Nevertheless, plan policies could encourage developments which support this kind of outcome.

- Well-being, therefore, represents a measurable outcome for marine planning systems and plans. However, to date, few national marine planning systems have engaged with this topic extensively or set up an established metric to evaluate this outcome.

- Within current MSP processes, there is a widespread lack of understanding and, therefore, reliable and credible evidence associated with these more sociocultural components of marine management.

- Socio-cultural aspects of societal relationships with the sea are subject to spatial and temporal variation, as well as having the unique issue of being a landscape/environment that is often quite removed from everyday public experience. This lack of public awareness and connection with the marine environment poses a real challenge to MSP.

- A layer of complexity is added through a domination of studies that explore and/or measure socio-cultural metrics at a local or regional level. Scaling this up to a national, or even a regional MPA level, is challenging, and there has been limited success to date. 
- MSP has an opportunity to lead the way in developing a standardised approach to this evidence need, supporting the realisation of global goals of a broader, more holistic approach to marine planning and wider marine governance.

MSP is still a relatively new mechanism within broader marine and coastal management. The emerging and evolutionary nature of this process suggests there to be scope for the MSP process to evolve, and to establish mechanisms for the inclusion of these sociocultural aspects of societal relationships with the global seas. In summary, it is clear that, despite international goals and an ever-growing emphasis on the importance of considering the 'human' element of interactions within environmental governance, a lack of understanding about the flows and pathways to impact between these socio-cultural dimensions and MSP remains. The reason for the exclusion of these forms of evidence may range from resource constraints, to the complexities of knowledge generation, to whether the overall framing of the marine planning initiative is sympathetic to this kind of knowledge. Yet it is the socio-cultural dimension and the key concepts explored in this chapter that often provide the basis for engaging the public within the planning process and demonstrating the societal relevance of MSP. We, therefore, contend that there is much benefit to the future development of this knowledge base to support MSP.

Acknowledgements We are grateful to the project "Economy of maritime space" funded by the Polish National Science Centre for contributing the Open Access fee for this chapter and facilitating our discussions and preparation of the book.

\section{References}

Acott, T. G., \& Urquhart, J. (2017). Exploring CES and Wellbeing Through a Place Based Approach: The Case of SSF Along the English Channel. In D. Johnson, T. G. Acott, et al. (Eds.), Social Wellbeing and the Values of Small-Scale Fisheries. Springer.

Alegret, J.-L., \& Carbonell, E. (2016). Maritime Heritage Conservation. In H. D. Smith, J. L. S. De Vivero, \& T. S. Agardy (Eds.), Routledge Handbook of Ocean Resources and Management. Routledge.

Arkema, K. K., Verutes, G. M., Wood, S. A., Clarke-Samuels, C., Rosado, S., Canto, M., Rosenthal, A., Ruckelshaus, M., Guannel, G., Toft, J., Faries, J., Silver, J. M., Griffin, R., \& Guerry, A. D. (2015). Embedding Ecosystem Services in Coastal Planning Leads to Better Outcomes for People and Nature. Proceedings of the National Academy of Sciences of the United States of America, 112, 7390-7395. 
Barbier, E. B., Hacker, S. D., Kennedy, C., Koch, E. W., Stier, A. C., \& Silliman, B. R. (2011). The Value of Estuarine and Coastal Ecosystem Services. Ecological Monographs, 81, 169-193.

Baulcomb, C., Fletcher, R., Lewis, A., Akoglu, E., Robinson, L., Von Almen, A., Hussain, S., \& Glenk, K. (2015). A Pathway to Identifying and Valuing Cultural Ecosystem Services: An Application to Marine Food Webs. Ecosystem Services, 11, 128-139.

Beaumont, N. J., Austen, M. C., Atkins, J. P., Burdon, D., Degraer, S., Dentinho, T. P., Derous, S., Holm, P., Horton, T., Van Ierland, E., Marboe, A. H., Starkey, D. J., Townsend, M., \& Zarzycki, T. (2007). Identification, Definition and Quantification of Goods and Services Provided by Marine Biodiversity: Implications for the Ecosystem Approach. Marine Pollution Bulletin, 54, 253-265.

Biedenweg, K., Stiles, K., \& Wellman, K. (2016). A Holistic Framework for Identifying Human Well-Being Indicators for Marine Policy. Marine Policy, 64, 31-37. https://doi.org/10.1016/j.marpol.2015.11.002.

Börger, T., Beaumont, N. J., Pendleton, L., Boyle, K. J., Cooper, P., Fletcher, S., Haab, T., Hanemann, M., Hooper, T. L., Hussain, S. S., Portela, R., Stithou, M., Stockill, J., Taylor, T., \& Austen, M. C. (2014). Incorporating Ecosystem Services in Marine Planning: The Role of Valuation. Marine Policy, 46, 161-170. https:// doi.org/10.1016/j.marpol.2014.01.019.

Braat, L. C. (2018). Five Reasons Why the Science Publication "Assessing Nature's Contributions to People" (Diaz et al. 2018) Would Not Have Been Accepted in Ecosystem Services. Ecosystem Services, 30, A1-A2.

Breslow, S. J., Sojka, B., Barnea, R., Basurto, X., Carothers, C., Charnley, S., Coulthard, S., Dolšak, N., Donatuto, J., García-Quijano, C., Hicks, C. C., Levine, A., Mascia, M. B., Norman, K., Poe, M., Satterfield, T., Martin, K. S., \& Levin, P. S. (2016). Conceptualizing and Operationalizing Human Well-Being for Ecosystem Assessment and Management. Environmental Science and Policy, 66, 250-259. https://doi.org/10.1016/j.envsci.2016.06.023.

Bryce, R., Irvine, K. N., Church, A., Fish, R., Ranger, S., \& Kenter, J. O. (2016). Subjective Well-Being Indicators for Large-Scale Assessment of Cultural Ecosystem Services. Ecosystem Services, 21, 258-269.

Cooper, N., Brady, E., Steen, H., \& Bryce, R. (2016). Aesthetic and Spiritual Values of Ecosystems: Recognising the Ontological and Axiological Plurality of Cultural Ecosystem 'Services'. Ecosystem Services.

Costa, S., \& Calderia, R. (2018). Bibliometric Analysis of Ocean Literacy: An Underrated Term in the Scientific Literature. Marine Policy, 87, 149-157.

Costanza, R., De Groot, R., Braat, L., Kubiszewski, I., Fioramonti, L., Sutton, P., Farber, S., \& Grasso, M. (2017). Twenty Years of Ecosystem Services: How Far Have We Come and How Far Do We Still Need to Go? Ecosystem Services, 28, $1-16$. 
Coulthard, S. (2012). What Does the Debate Around Social Well-Being Have to Offer Sustainable Fisheries? Current Opinion in Environmental Sustainability, 4(3), 358-363. https://doi.org/10.1016/j.cosust.2012.06.001.

Daw, T. M., Coulthard, S., Cheung, W. W. L., Brown, K., Abunge, C., Galafassi, D., Peterson, G. D., McClanahan, T. R., Omukoto, J. O., \& Munyi, L. (2015). Evaluating Taboo Trade-Offs in Ecosystems Services and Human Well-Being. Proceedings of the National Academy of Sciences of the United States of America, 112(22), 6949-6954. https://doi.org/10.1073/pnas.1414900112.

DEFRA. (2011). UK Marine Policy Statement. Retrieved June 20, 2018, from https://www.gov.uk/government/publications/uk-marine-policy-statement.

Dempsey, J., \& Robertson, M. M. (2012). Ecosystem Services: Tensions, Impurities and Points of Engagement Within Neoliberalism. Progress in Human Geography, 36(6), 758-779.

Edwards, D. M., Collins, T. M., \& Goto, R. (2016). An Arts-Led Dialogue to Elicit Shared, Plural and Cultural Values of Ecosystems. Ecosystem Services, 21, 319-328.

Falconer, L., Hunter, D. C., Telfer, T. C., \& Ross, L. G. (2013). Visual, Seascape and Landscape Analysis to Support Coastal Aquaculture Site Selection. Land Use Policy, 34, 1-10. https://doi.org/10.1016/j.landusepol.2013.02.002.

Fish, R., Church, A., \& Winter, M. (2016). Conceptualising Cultural Ecosystem Services: A Novel Framework for Research and Critical Engagement. Ecosystem Services.

Fletcher, S., \& Potts, J. (2007). Ocean Citizenship: An Emergent Geographical Concept. Coastal Management, 35(4), 511-524. https://doi.org/10.1080/089207 50701525818.

Fletcher, S., Saunders, J., \& Herbert, R. J. H. (2011). A Review of the Ecosystem Services Provided by Broad-Scale Marine Habitats.pdf. Journal of Coastal Research, 64, 378-383.

Fletcher, S., Jefferson, R. L., \& McKinley, E. (2012). Saving the Shallows: Focusing Marine Conservation Where People Might Care. Aquatic Conservation: Marine and Freshwater Ecosystems.

Fletcher, R., Baulcomb, C., Hall, C., \& Hussain, S. (2014). Revealing Marine Cultural Ecosystem Services in the Black Sea. Marine Policy, 50, 151-161.

Foley, R. (2015). Swimming in Ireland: Immersions in Therapeutic Blue Space. Health and Place, 35, 218-225. https://doi.org/10.1016/j.healthplace.2014.09.015.

Gascon, M., Zijlema, W., Vert, C., White, M. P., \& Nieuwenhuijsen, M. J. (2017). Outdoor Blue Spaces, Human Health and Well-Being: A Systematic Review of Quantitative Studies. International Journal of Hygiene and Environmental Health, 220(8), 1207-1221. https://doi.org/10.1016/j.ijheh.2017.08.004.

Gee, K., Kannen, A., Adlam, R., Brooks, C., Chapman, M., Cormier, R., Fischer, C., Fletcher, S., Gubbins, M., Shucksmith, R., \& Shellock, R. (2017). Identifying Culturally Significant Areas for Marine Spatial Planning. Ocean \& Coastal Management, 136, 139-147. 
Gómez-Baggethun, E., De Groot, R., Lomas, P. L., \& Montes, C. (2010). The History of Ecosystem Services in Economic Theory and Practice: From Early Notions to Markets and Payment Schemes. Ecological Economics, 69, 1209-1218. Guerry, A. D., Ruckelshaus, M. H., Arkema, K. K., Bernhardt, J. R., Guannel, G., Kim, C.-K., Marsik, M., Papenfus, M., Toft, J. E., Verutes, G., Wood, S. A., Beck, M., Chan, F., Chan, K. M. A., Gelfenbaum, G., Gold, B. D., Halpern, B. S., Labiosa, W. B., Lester, S. E., Levin, P. S., Mcfield, M., Pinsky, M. L., Plummer, M., Polasky, S., Ruggiero, P., Sutherland, D. A., Tallis, H., Day, A., \& Spencer, J. (2012). Modeling Benefits from Nature: Using Ecosystem Services to Inform Coastal and Marine Spatial Planning. International Journal of Biodiversity Science, Ecosystem Services \& Management, 8, 107-121.

Halpern, B. S., Diamond, J., Gaines, S., Gelcich, S., Gleason, M., Jennings, S., Lester, S., Mace, A., Mccook, L., Mcleod, K., Napoli, N., Rawson, K., Rice, J., Rosenberg, A., Ruckelshaus, M., Saier, B., Sandifer, P., Scholz, A., \& Zivian, A. (2012). Near-Term Priorities for the Science, Policy and Practice of Coastal and Marine Spatial Planning (CMSP). Marine Policy, 36, 198-205.

Hattam, C., Atkins, J. P., Beaumont, N., Borger, T., Bohnke-Henrichs, A., Burdon, D., De Groot, R., Hoefnagel, E., Nunes, P. A. L. D., Piwowarczyk, J., Sastre, S., \& Austen, M. C. (2015). Marine Ecosystem Services: Linking Indicators to Their Classification. Ecological Indicators, 49, 61-75.

Hawthorne, M., \& Alabaster, T. (1999). Citizen 2000 Development of a Model of Environmental Citizenship. Global Environmental Change, 9, 25-43.

Hynes, S., Ghermandi, A., Norton, D., \& Williams, H. (2018). Marine Recreational Ecosystem Service Value Estimation: A Meta-Analysis with Cultural Considerations. Ecosystem Services.

Ives, C. D., \& Kendal, D. (2014). The Role of Social Values in the Management of Ecological Systems. Journal of Environmental Management, 144, 67-72.

Jefferson, R. L., Bailey, I., Laffoley, D. D., Richards, J. P., \& Attrill, M. (2014). Public Perceptions of the UK Marine Environment. Marine Policy, 43, 327-337.

Jefferson, R., McKinley, E., Capstick, S., Fletcher, S., Griffin, H., \& Milanese, M. (2015). Understanding Audiences: Making Public Perceptions Research Matter to Marine Conservation. Ocean and Coastal Management. https://doi.org/10.1016/j. ocecoaman.2015.06.014.

Jobstvogt, N., Watson, V., \& Kenter, J. O. (2014). Looking Below the Surface: The Cultural Ecosystem Service Values of UK Marine Protected Areas (MPAs). Ecosystem Services, 10, 97-110.

Johnson, D., Acott, T. G., Stacey, N., \& Urquhart, J. (Eds.). (2017). Social Wellbeing and the Values of Small-Scale Fisheries. Springer.

Kallis, G., Gomez-Baggethun, E., \& Zograios, C. (2013). To Value or Not to Value? That Is not the Question. Ecological Economics, 94, 97-105. 
Kearns, R., \& Collins, D. (2012). Feeling for the Coast: The Place of Emotion in Resistance to Residential Development. Social \& Cultural Geography, 13(8), 937-955. https://doi.org/10.1080/14649365.2012.730150.

Kenter, J. O., O’brien, L., Hockley, N., Ravenscroft, N., Fazey, I., Irvine, K. N., Reed, M. S., Christie, M., Brady, E., Bryce, R., Church, A., Cooper, N., Davies, A., Evely, A., Everard, M., Fish, R., Fisher, J. A., Jobstvogt, N., Molloy, C., Orchard-Webb, J., Ranger, S., Ryan, M., Watson, V., \& Williams, S. (2015). What Are Shared and Social Values of Ecosystems? Ecological Economics, 111, 86-99.

Kenter, J. O., Bryce, R., Christie, M., Cooper, N., Hockley, N., Irvine, K. N., Fazey, I., O'brien, L., Orchard-Webb, J., Ravenscroft, N., Raymond, C. M., Reed, M. S., Tett, P., \& Watson, V. (2016a). Shared Values and Deliberative Valuation: Future Directions. Ecosystem Services, 21, 358-371.

Kenter, J. O., Jobstvogt, N., Watson, V., Irvine, K. N., Christie, M., \& Bryce, R. (2016b). The Impact of Information, Value-Deliberation and Group-Based Decision-Making on Values for Ecosystem Services: Integrating Deliberative Monetary Valuation and Storytelling. Ecosystem Services, 21, 270-290.

Klain, S. C., \& Chan, K. M. A. (2012). Navigating Coastal Values: Participatory Mapping of Ecosystem Services for Spatial Planning. Ecological Economics, 82, 104-113.

Leyshon, C. (2014). Cultural Ecosystem Services and the Challenge for Cultural Geography. Geography Compass, 8, 710-725.

Liquete, C., Piroddi, C., Drakou, E. G., Gurney, L., Katsanevakis, S., Charef, A., \& Egoh, B. (2013). Current Status and Future Prospects for the Assessment of Marine and Coastal Ecosystem Services: A Systematic Review. PLoS One, 8, e67737.

Luisetti, T., Turner, R. K., Jickells, T., Andrews, J., Elliott, M., Schaafsma, M., Beaumont, N., Malcolm, S., Burdon, D., Adams, C., \& Watts, W. (2014). Coastal Zone Ecosystem Services: From Science to Values and Decision Making; a Case Study. Science of the Total Environment, 493, 682-693.

McGregor, J. A. (2014). Human Well-Being and Sustainability: Interdependent and Intertwined. In Handbook of Sustainable Development (2nd ed., pp. 217-233).

McGregor, J., \& Pouw Nicky, A. (2017). Towards an Economics of Wellbeing. Cambridge Journal of Economics, 41(4), 1123-1142. https://doi.org/10.1093/cje/ bew044.

McGregor, J. A., Camfield, L., \& Coulthard, S. (2015). Competing Interpretations: Human Well-Being and the Use of Quantitative and Qualitative Methods. In K. Roelen \& L. Camfield (Eds.), Mixed Methods Research in Poverty and Vulnerability: Sharing Ideas and Learning Lessons (pp. 231-260). London: Palgrave Macmillan. 
McKinley, E., \& Fletcher, S. (2010). Individual Responsibility for the Oceans? An Evaluation of Marine Citizenship by UK Marine Practitioners. Ocean and Coastal Management, 53(7), 379-384.

McKinley, E., \& Fletcher, S. (2012). Improving Marine Environmental Health Through Marine Citizenship: A Call for Debate. Marine Policy, 36, 839-843. https://doi.org/10.1016/j.marpol.2011.11.001.

Millennium Ecosystem Assessment. (2003). Chapter 1: MA Conceptual Framework. In Millennium Ecosystem Assessment, Ecosystems and Human Well-being: A Framework for Assessment. Island Press.

Murray, G., D'anna, L., \& Macdonald, P. (2016). Measuring What We Value: The Utility of Mixed Methods Approaches for Incorporating Values into Marine Social-Ecological System Management. Marine Policy, 73, 61-68.

Natural England. (2012). An Approach to Seascape Character Assessment. Report NECR105. Peterborough: Natural England.

OECD. (2011). How's Life? Measuring Well-Being. Paris: OECD.

Potts, T., Burdon, D., Jackson, E., Atkins, J., Saunders, J., Hastings, E., \& Langmead, O. (2014). Do Marine Protected Areas Deliver Flows of Ecosystem Services to Support Human Welfare? Marine Policy, 44, 139-148.

Potts, T., Pita, C., O’Higgins, T., \& Mee, L. (2016). Who Cares? European Attitudes Towards Marine and Coastal Environments. Marine Policy, 72, 59-66.

Ranger, S., Kenter, J. O., Bryce, R., Cumming, G., Dapling, T., Lawes, E., \& Richardson, P. B. (2016). Forming Shared Values in Conservation Management: An Interpretive-Deliberative-Democratic Approach to Including Community Voices. Ecosystem Services.

Ruiz-Frau, A., Hinz, H., Edwards-Jones, G., \& Kaiser, M. J. (2013). Spatially Explicit Economic Assessment of Cultural Ecosystem Services: Non-extractive Recreational Uses of the Coastal Environment Related to Marine Biodiversity. Marine Policy, 38, 90-98.

Russell, R., Guerry, A. D., Balvanera, P., Gould, R. K., Basurto, X., Chan, K. M. A., Klain, S., Levine, J., \& Tam, J. (2013). Humans and Nature: How Knowing and Experiencing Nature Affect Well-Being. Annual Review of Environment and Resources, 38, 473-502. https://doi.org/10.1146/ annurev-environ-012312-110838.

Satz, D., Gould, R. K., Chan, K. M., Guerry, A., Norton, B., Satterfield, T., Halpern, B. S., Levine, J., Woodside, U., Hannahs, N., Basurto, X., \& Klain, S. (2013). The Challenges of Incorporating Cultural Ecosystem Services into Environmental Assessment. Ambio, 42, 675-684.

Saunders, J., Beaumont, N., Atkins, J. P., Lannin, A., Lear, D., Ozdemiroglu, E., \& Potts, T. (2015). A Review of Marine and Coastal Ecosystem Services Data and Tools to Incorporate This into Decision-Making. In K. R. Turner \& M. Schaafsma (Eds.), Coastal Zones Ecosystem Services: From Science to Values and Decision Making. Springer International Publishing. 
Schwartz, S. H. (1992). Universals in the Content and Structure of Values: Theoretical Advances and Empirical Tests in 20 Countries. Advances in Experimental Social Psychology, 25, 1-65.

Smith, H. D., Ballinger, R. C., \& Stojanovic, T. A. (2012). The Spatial Development Basis of Marine Spatial Planning in the United Kingdom. Journal of Environmental Policy and Planning, 14(1), 29-47. https://doi.org/10.1080/1523908x.2012. 663192.

Steel, B. S., Smith, C., Opsommer, L., Curiel, S., \& Warner-Steel, R. (2005). Public Ocean Literacy in the United States. Ocean and Coastal Management, 48(2), 97-114.

Stiglitz, J. E., Sen, A. K., \& Fitoussi, J.-P. (2009). Measuring Economic Performance and Social Progress, Paris, Commission on the Measurement of Economic Performance and Social Progress.

Stojanovic, T. A., \& Farmer, C. J. Q. (2014). The Development of World Oceans \& Coasts and Concepts of Sustainability. Marine Policy, 42, 157-165.

Tallis, H., Kareiva, P., Marvier, M., \& Chang, A. (2008). An Ecosystem Services Framework to Support Both Practical Conservation and Economic Development. PNAS, 105(28), 9457-9464.

The Guardian. (2018). The Blue Planet Effect: Why Marine Biology Courses Are Booming. Retrieved June 20, 2018, from https://www.theguardian.com/education/2018/jan/12/blue-planet-effect-why-marine-biology-courses-booming.

Turner, K. R., \& Schaafsma, M. (Eds.). (2015). Coastal Zones Ecosystem Services: From Science to Values and Decision Making. Springer International Publishing.

UK Government. (2018). A Green Future-Our 25 Year Plan to Improve the Environment. Retrieved June 20, 2018, from https://www.gov.uk/government/ publications/25-year-environment-plan.

United Nations. (2015). Sustainable Development Goals. Retrieved June 15, 2018, from https://sustainabledevelopment.un.org/?menu=1300.

Urquhart, J., \& Acott, T. G. (2013). Re-connecting and Embedding Food in Place: Rural Development and Inshore Fisheries in Cornwall, UK. Journal of Rural Studies, 32, 357-364.

Uyarra, M. C., \& Borja, A. (2016). Ocean Literacy: A 'New' Socio-Ecological Concept for a Sustainable Use of the Seas. Marine Pollution Bulletin, 104, 1-2.

White, C. (2017). Symbols of Resilience and Contested Place Identity in the Coastal Fishing Towns of Cromer and Sheringham, Norfolk, UK: Implications for Social Wellbeing. In D. Johnson, T. G. Acott, N. Stacey, \& J. Urquhart (Eds.), Social Wellbeing and the Values of Small-Scale Fisheries (pp. 45-74). Springer.

White, M. P., Weeks, A., Hooper, T., Bleakley, L., Cracknell, D., Lovell, R., \& Jefferson, R. L. (2017). Marine Wildlife as an Important Component of Coastal Visits: The Role of Perceived Biodiversity and Species Behaviour. Marine Policy, 78, 80-89. https://doi.org/10.1016/j.marpol.2017.01.005. 
Wyles, K. J., White, M. P., Hattam, C., Pahl, S., King, H., \& Austen, M. (2017). Are Some Natural Environments More Psychologically Beneficial Than Others? The Importance of Type and Quality on Connectedness to Nature and Psychological Restoration. Environment and Behavior. https:// doi.org/10.1177/0013916517738312.

Zufferey, J. (2015). Relationships Between Health and Green and Blue Spaces: A Synthesis of Empirical Research, 2003-2014. Natures Sciences Societes, 23(4), 343-355. https://doi.org/10.1051/nss/2015057.

Open Access This chapter is licensed under the terms of the Creative Commons Attribution 4.0 International License (http://creativecommons.org/licenses/by/4.0/), which permits use, sharing, adaptation, distribution and reproduction in any medium or format, as long as you give appropriate credit to the original author(s) and the source, provide a link to the Creative Commons licence and indicate if changes were made.

The images or other third party material in this chapter are included in the chapter's Creative Commons licence, unless indicated otherwise in a credit line to the material. If material is not included in the chapter's Creative Commons licence and your intended use is not permitted by statutory regulation or exceeds the permitted use, you will need to obtain permission directly from the copyright holder.

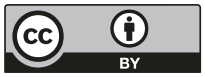

